\title{
1 Fertilizer potential of liquid product from hydrothermal treatment of
}

\section{2 swine manure}

3 Tian Yuan ${ }^{\mathrm{a}, 1}$, Yanfei Cheng ${ }^{\mathrm{a}, 1}$, Weiwei Huang ${ }^{\mathrm{b}}$, Zhenya Zhang ${ }^{\mathrm{a}}$, Zhongfang Lei ${ }^{\mathrm{a}, *}$,

4 Kazuya Shimizu ${ }^{\mathrm{a}}$, Motoo Utsumi ${ }^{\mathrm{a}}$

5 a Graduate School of Life and Environmental Sciences, University of Tsukuba, 1-1-1

6 Tennodai, Tsukuba, Ibaraki 305-8572, Japan.

$7 \quad$ b Key Laboratory of Coal Gasification and Energy Chemical Engineering of Ministry of

8 Education, East China University of Science and Technology, No. 130 Meilong Road,

$9 \quad$ Shanghai 200237, China

$10 *$ Corresponding author.

11 E-mail: lei.zhongfang.gu@u.tsukuba.ac.jp(Z. Lei)

$12{ }^{1}$ The authors contributed equally to this work. 


\section{Abstract}

14 Compared with composting, hydrothermal treatment (HTT) technology can

15 dramatically shorten the duration for manure waste treatment. This study firstly

16 investigated the effect of HTT on solubilization of N, P and organics from swine

17 manure, and then evaluated the phytotoxicity of liquid product from hydrothermally

18 treated manure by seed germination test. Results show that $98 \%$ of $\mathrm{N}$ in manure could

19 be converted into soluble form after HTT at $200^{\circ} \mathrm{C}$ for $60 \mathrm{~min}$. Soluble P in

20 hydrothermally treated manure (at $150^{\circ} \mathrm{C}$ for $60 \mathrm{~min}$ ) was 2.7 times that in raw manure.

21 The germination indices (GI) were all greater than 100\% when the liquid product (from

$22 \mathrm{HTT}$ at $150^{\circ} \mathrm{C}$ for $60 \mathrm{~min}$ ) or its diluted samples being used. Results from this study

23 suggest that HTT could be a promising technology for producing safe and value-added

24 liquid fertilizers from swine manure. 
Nutrients are essential for plant growth. To insure enough food production from the limited farmland on Earth for the increasing global population, fertilizers play an important role in the increase of plant yield and remediation of soil depletion resulted from intensive farming activities. However, long-term application of chemical fertilizers shows negative effect on soil's $\mathrm{N}$ and $\mathrm{C}$ storage capacities and agronomic efficiency (Khan et al., 2007; Mulvaney et al., 2009). In addition, the production of synthetic

fertilizer requires a large amount of gases, energy (Haber-Bosch process for $\mathrm{N}$ ) and natural mineral resources (like phosphate rock) (Teenstra et al., 2014).

Nutrients recovery from organic wastes can become a prospective option if the process's environmental friendliness and sustainability could be guaranteed. As a result of the increasing global population, one important sector of food production, animal husbandry has also been rapidly developed, generating far more manure than the amount needed by local farmers for land application (He et al., 2016). Composting is a typical method widely used to convert manure waste to fertilizer that can be safely used, since the process can stabilize organics, sterilize pathogens and weed seeds in raw manure (Eghball and Lesoing, 2000). However, in terms of manure waste treatment and resources recovery, composting might be less efficient, since after long time processing, the major beneficial and finished product is compost only. During the long period of composting process, around half of the $\mathrm{C}$ and $\mathrm{N}$ sources would be lost and emitted as harmful and greenhouse gases (GHGs) (Hao et al., 2004), demonstrating its low environmental friendliness and sustainability.

In order to reduce nutrients loss and develop a highly efficient process to convert 
manure waste into safe fertilizers, hydrothermal treatment (HTT) technology was attempted in this study, since the high temperature used (above $100^{\circ} \mathrm{C}$ ) can release high content of nutrients and sterilize pathogens (Barber, 2016). The solid residue is expected to produce biogas via dry anaerobic digestion (AD) process. Most recently, Huang et al. (2017) pointed out the possibility of using the water extract from hydrothermally treated manure as liquid fertilizer, and the solid fraction can achieve $51 \%$ increase in $\mathrm{CH}_{4}$ yield by dry $\mathrm{AD}$. In addition, the resultant dry $\mathrm{AD}$ residue can be further used as solid fertilizer. HTT as a treatment method has been tried on sewage sludge for enhanced sludge dewaterability and improved subsequent $\mathrm{AD}$ (Li et al., 2017). In recent years, increasing attention has been paid to recovery of valuable compounds from solid wastes by using HTT (Suárez-Iglesias et al., 2017; Aida et al., 2017). For instance, when microalgae were hydrothermally treated at $175-350^{\circ} \mathrm{C}$ for $10-90 \mathrm{~min}, 38-100 \%$ of nitrogen $(\mathrm{N})$ and $57-99 \%$ of phosphorus $(\mathrm{P})$ could be recovered in the water-soluble fraction (Aida et al., 2017). They also found that when HTT was performed at lower temperature than $200^{\circ} \mathrm{C}$, organic $\mathrm{N}$ was the predominant $\mathrm{N}$ form in the water-soluble fraction. The high nutrients recovery rate with high organic $\mathrm{N}$ content reflects the great potential of HTT technology for nutrients recovery and liquid fertilizer production from manure waste. Idowu et al. (2017) also mentioned the fertilizer potential of process water from food waste after hydrothermal process. Restated, although previous research works have pointed out the fertilizer potential of liquid product from sludge, chicken feathers and empty fruit bunch by using HTT (Gollakota et al., 2018; Sun et al., 2014; Nurdiawati et al., 2015; Nurdiawati et al., 2018), the said liquid fertilizer potential has rarely been explored. In addition, limited information could be found on the feasibility 
of liquid fertilizer production from manure waste by using HTT, let alone the nutrients variation of treated manure at lower temperature than $200^{\circ} \mathrm{C}$.

This study aimed to investigate the fertilizer potential of liquid product from HTT of swine manure. The effects of treatment temperature $\left(110-200^{\circ} \mathrm{C}\right)$ and retention time $(0-$ $60 \mathrm{~min}$ ) on soluble $\mathrm{N}$ and $\mathrm{P}$, soluble organics (carbohydrate, protein and volatile fatty acids (VFAs)) were clarified. The properties of liquid product were further demonstrated by seed germination test and its $\mathrm{pH}$, electric conductivity (EC), and metal ions.

\section{Material and methods}

\subsection{Swine manure}

Swine manure used in this study was sampled from a local farm in Tsukuba, Ibaraki, Japan. The pigs were raised in traditional pig houses with cement floor. The manure was collected as solid state and stored at $4^{\circ} \mathrm{C}$ before use. The main characteristics of swine manure were as follows: total solids (TS) $26.9 \pm 0.53 \%$ of fresh weight, volatile solids (VS) $20.1 \pm 0.42 \%$ of fresh weight, total nitrogen (TN) $27.7 \pm 1.02 \mathrm{~g} \mathrm{~N} / \mathrm{kg}-\mathrm{VS}$, soluble $\mathrm{N}$ $11.1 \pm 0.33 \mathrm{~g} \mathrm{~N} / \mathrm{kg}$-VS, total phosphorus (TP) $25.8 \pm 0.50 \mathrm{~g} \mathrm{P} / \mathrm{kg}$-TS, and soluble $\mathrm{P}$ $1.7 \pm 0.08 \mathrm{~g} \mathrm{P} / \mathrm{kg}-\mathrm{TS}$.

\subsection{Hydrothermal treatment}

Hydrothermal treatment (HTT) trials were conducted in an enclosed stainless reactor equipped with a propeller stirrer (OM Lab-tech MMJ-200, Japan). The reactor has a working volume of $200 \mathrm{ml}$ and maximum temperature of $300^{\circ} \mathrm{C}$. These trials, each in triplicate, were performed at different temperature $\left(110,150,180\right.$, or $\left.200^{\circ} \mathrm{C}\right)$ for different retention time $(0,10,30$, or $60 \mathrm{~min})$ with agitation $(60 \mathrm{rpm})$. For each trial, 80 
gram of raw swine manure was loaded into the reactor. After maintaining at different temperature for a designated retention time, the reactor was cooled to room temperature. Then, the treated swine manure was collected for further analysis. The schematic of experimental setup is illustrated in Fig. 1.

Soluble organic carbon (SOC), proteins, carbohydrates, volatile fatty acids (VFAs), ammonia nitrogen, orthophosphate, total solids (TS) and volatile solids (VS) contents, and $\mathrm{pH}$ of each sample were determined according to the procedures and methods described elsewhere (Yuan et al., 2017). Soluble N was detected with alkaline potassium persulfate digestion and UV spectrophotometric method. Soluble P was determined according to the phosphomolybdenum blue method after potassium persulfate digestion (APHA, 2012). Metal ions were analyzed by ICP-OES (Perkin Elmer Optima 7300DV) after the sample being completely digested with the mixture of $\mathrm{HNO}_{3}$ and $\mathrm{H}_{2} \mathrm{O}_{2}(1: 1$, $\mathrm{v} / \mathrm{v})$ at $98^{\circ} \mathrm{C}$.

\subsection{Seed germination test}

Seed germination was conducted to evaluate the phytotoxicity of swine manure after HTT. The seeds of Komatsuna were chosen for this germination test. The filtrates of treated manure after $\mathrm{HTT}$ at $150^{\circ} \mathrm{C}$ for $60 \mathrm{~min}(150-60), 180^{\circ} \mathrm{C}$ for $30 \mathrm{~min}(180-30)$, $200^{\circ} \mathrm{C}$ for $60 \mathrm{~min}(200-60)$ were diluted correspondingly to a SOC concentration of 500,1000 , or $2000 \mathrm{mg} / \mathrm{L}$. For each test, $1.5 \mathrm{ml}$ filtrate or distilled water was added on the filter paper in a petri dish where 15 seeds were placed. Three petri dishes were prepared for each condition. Then, the germination test was conducted at $30^{\circ} \mathrm{C}$ and $60 \%$ of humidity. After 72 hours' incubation, the number of viable seeds and the root length in each test were measured and recorded. Besides, the electric conductivity (EC) and $\mathrm{pH}$ 
of each filtrate used for germination test were measured. Germination index (GI) was calculated using the following equation (Tiquia and Tam, 1998).

$$
\text { Germination index }(\%)=\frac{n_{s} \times \text { Root length in filtrate }}{n_{c} \times \text { Root length in control }} \times 100
$$

where $n_{s}$ is the number of germinated seed in the tested filtrate sample, and $n_{c}$ is the number of germinated seed in the control (distilled water).

\subsection{Statistical analysis}

The analysis of variance (ANOVA) was applied to analyze the statistical difference of $\mathrm{N}, \mathrm{P}$ and organics solubilization at different HTT conditions (temperature and retention time). Pearson's correlation coefficients were calculated to show the relationship between GI and chemical properties of liquid products at different SOC levels. All the statistical analyses were conducted by using IBM SPSS Statistics 20.0.

\section{Results and discussion}

\subsection{Effect of HTT on solubilization}

\subsubsection{Organics solubilization}

The soluble organic carbon (SOC) concentration and resultant $\mathrm{pH}$ in swine manure after HTT are shown in Fig. 2. As seen, the highest SOC concentration achieved after HTT at $180^{\circ} \mathrm{C}$ for 30 min was 4.1 times that in the raw swine manure, in agreement with the statement by Barber et al. (2016) who claimed that the optimal temperature and duration for thermal hydrolysis were around $160-180^{\circ} \mathrm{C}$ and $20-40$ min, respectively. When HTT was conducted at higher temperatures $\left(180^{\circ} \mathrm{C}\right.$ or $\left.200^{\circ} \mathrm{C}\right)$, the SOC concentration in the treated manure began to decrease when the treatment lasted for longer than $30 \mathrm{~min}$ or $10 \mathrm{~min}$, respectively. 
The concentrations of VFAs, soluble carbohydrates and proteins varied with HTT conditions (treatment temperature and retention time). VFAs concentration in the treated manure did not show much change after $\mathrm{HTT}$ at $110^{\circ} \mathrm{C}$ and $150^{\circ} \mathrm{C}$. When HTT temperature increased to $180^{\circ} \mathrm{C}$ or $200^{\circ} \mathrm{C}$, the VFAs concentration increased with the prolongation of retention time, and it was about 2 times that in the raw swine manure after treatment for $60 \mathrm{~min}$. As for soluble carbohydrates, its concentration decreased obviously at higher temperatures $\left(180^{\circ} \mathrm{C}\right.$ and $\left.200^{\circ} \mathrm{C}\right)$ for a longer retention time. The carbohydrates may be hydrolyzed into monosaccharide at lower temperature and further generate larger molecular compounds at higher temperature for a longer retention time (Gai et al., 2015). For instance, Maillard reaction might occur between reducing sugar and amino acids in the temperature range of $140-165^{\circ} \mathrm{C}$ (Barber et al., 2016). The highest soluble carbohydrate was $13.7 \mathrm{~g} \mathrm{C} / \mathrm{kg}$-VS (about 4.4 times that in the raw swine manure) after $\mathrm{HTT}$ at $150^{\circ} \mathrm{C}$ for $60 \mathrm{~min}$. Soluble proteins occupied a large portion of SOC in the treated manure, about 15.3 times that in the raw swine manure after HTT at $180^{\circ} \mathrm{C}$ for $30 \mathrm{~min}$. However, under the highest temperature $\left(200^{\circ} \mathrm{C}\right)$ tested in this study, a longer retention time exhibited decrease effect on soluble protein concentration, possibly attributable to its decomposition into peptide or amino acids under this condition. Except for VFAs, carbohydrates and proteins, large amount of other soluble organics were also dissolved in the liquid phase. The $\mathrm{pH}$ generally decreased along with the HTT duration and the increase in temperature. However, the increase of VFAs production was milder compared to the drastic decrease of $\mathrm{pH}$. This might be due to more efficient decomposition or hydrolysis of organics and production of other acidic compounds under higher HTT temperature conditions. As Gollakota et al. (2016) 
pointed out, pyrolysis liquids generally have an acidic character.

\subsection{2. $N$ and $P$ solubilization}

Fig. 3a illustrates the ammonia $\mathrm{N}$ and organic $\mathrm{N}$ in the soluble fraction of swine manure after HTT at different temperature for a designated retention time. The highest soluble $\mathrm{N}$ concentration was achieved at $200^{\circ} \mathrm{C}$ for $60 \mathrm{~min} .98 \%$ of $\mathrm{TN}$ in the manure was dissolved and transferred to the soluble fraction (Fig. 3b). It was found that the soluble $\mathrm{N}$ in swine manure increased with the increase in HTT temperature, and became relatively stable when the temperature $>180^{\circ} \mathrm{C}$. Seen from Fig. $3 \mathrm{~b}$, the $\mathrm{N}$ dissolution ratio gradually increased with the retention time, from $71.3 \%$ ( $0 \mathrm{~min})$ to $85.0 \%$ (30 $\mathrm{min})$, then slightly decreased $(80.9 \%)$ when the retention time was further prolonged to 60 min at $180^{\circ} \mathrm{C}$. Aida et al. (2017) observed a similar phenomenon that $\mathrm{N}$ yield in the water-soluble fraction decreased when $\mathrm{HTT}$ at $200^{\circ} \mathrm{C}$ lasted longer than $30 \mathrm{~min}$. In addition, ammonia $\mathrm{N}$ concentration showed almost a similar increase trend with soluble $\mathrm{N}$ when HTT was conducted at temperature lower than $180^{\circ} \mathrm{C}$. However, ammonia $\mathrm{N}$ was noticed to significantly decrease with the prolongation of retention time at $200^{\circ} \mathrm{C}$. The decreased ammonia $\mathrm{N}$ might replace the hydroxyl groups in the long-chain fatty acids to form aliphatic amine compounds or react with propanoic acid to produce propionic amide at $200^{\circ} \mathrm{C}$ for a longer retention time (Gai et al., 2015). The organic $\mathrm{N}$ in liquid phase may also further repolymerize and transfer to oil phase or other insoluble form at higher HTT temperature $\left(>200^{\circ} \mathrm{C}\right)$, which favors the production of bio-oil (Zheng et al., 2015). Although many researchers studied the possible pathways during HTT under different temperatures (Gai et al., 2015; Gollakota et al., 2018), more detailed investigations are still necessary since much more complex reactions are 
involved in HTT due to the different components in different substrates.

$$
\text { The solubilization of P in swine manure after HTT was also investigated (Fig. S1). }
$$

The multi-factor analysis of variance (ANOVA) showed that the soluble P after HTT at $150^{\circ} \mathrm{C}$ was significantly higher than those conducted at other temperatures, while the retention time did not have significant effect on $\mathrm{P}$ dissolution ratio. The soluble $\mathrm{P}$ increased by 2.8 times after $\mathrm{HTT}$ at $150^{\circ} \mathrm{C}$ for $60 \mathrm{~min}$ or $200^{\circ} \mathrm{C}$ for $0 \mathrm{~min}$, achieving the highest P dissolution ratio of around 13\% (Fig. S1), which agrees with the finding by Ekpo et al. (2016) who obtained water extractable $<15 \%$ of P from swine manure after being treated at $170^{\circ} \mathrm{C}$ for $1 \mathrm{~h}$. HTT at higher temperatures $\left(180^{\circ} \mathrm{C}\right.$ or $\left.200^{\circ} \mathrm{C}\right)$ resulted in decreased P dissolution ratio. Similar results could be found in previous researches (Aida et al., 2017; Ekpo et al., 2016), possibly due to the fact that precipitation of phosphate with multivalent metal ions became more easily at higher temperatures. The results of metal ions analysis by using ICP-OES in this study indicated that calcium concentration in the liquid decreased with the increase in temperature and prolongation of retention time, while increase in magnesium concentration was detectable in the liquid (Table 1). Thus, the formation of $\mathrm{Ca}_{3}\left(\mathrm{PO}_{4}\right)_{2}$ might be the major reason for the decreased soluble P (Aida et al., 2017). However, higher P dissolution was also found at $200^{\circ} \mathrm{C}$ for 0 min of retention time, probably due to a shorter retention time at higher temperature. Depolymerization is the dominant reaction during the initial stage of HTT, while repolymerization is usually active at later stage (Zheng et al., 2015). This observation is also in agreement with Aida et al. (2017) who obtained a higher P concentration in the water-soluble fraction after $\mathrm{HTT}$ at $250^{\circ} \mathrm{C}$ and $350^{\circ} \mathrm{C}$ for $10 \mathrm{~min}$.

\subsection{Seed germination test}



treated swine manure, the filtrates of swine manure after $\mathrm{HTT}$ at $150^{\circ} \mathrm{C}$ for $60 \mathrm{~min}$ (L150-60), $180^{\circ} \mathrm{C}$ for $30 \mathrm{~min}(\mathrm{~L} 180-30)$ and $200^{\circ} \mathrm{C}$ for $60 \mathrm{~min}$ (L200-60) were chosen to conduct seed germination test, due to their higher contents of soluble N, P, and organics. To make the results more comparable, the filtrates were diluted according to their SOC concentrations. The results of seed germination test are presented as germination index (GI). According to the Compost Maturity Index (CCQC, 2001), a GI higher than $90 \%$ indicates the phytotoxic-free property of the tested substrate which can be safely applied for soil. In this study, the liquid products from HTT at lower temperatures showed better behavior in the seed germination test when comparing their GI values at a same SOC level. The GI values by using either diluted or undiluted L15060 were all greater than $100 \%$ (Fig. 4), implying that it can be safely used for plant growth. Besides, the $\mathrm{pH}$ and $\mathrm{EC}$ of the filtrates (Table 1) were within the threshold values, which are 6.0-8.5 for $\mathrm{pH}$ and $4 \mathrm{mS} / \mathrm{cm}$ for EC, respectively (Crohn, 2016; Nurdiawati et al., 2015), again reflecting that the filtrates can be safely used for soil application and plant growth.

\subsection{Fertilizer potential of liquid product from hydrothermally treated swine}

\section{manure}

Except for macronutrients (N, P and K), small amounts of micronutrients are also required by plants for their growth. However, a higher concentration of micronutrients would inhibit plant growth. In this study, HTT promoted the solubilization of N, P, K and $\mathrm{Mg}$, while $\mathrm{Al}$ and $\mathrm{Cu}$ in the liquid products were found to decrease when compared with those in raw manure (Table 1). Although the concentrations of Fe and $\mathrm{Zn}$ increased 
to some extent after HTT, only 0.78 and $1.33 \mathrm{mg} / \mathrm{L}$ were detected in L150-60,

respectively, which are much lower than the reported limit values that inhibit plant growth and the national effluent standards in Japan (Arif et al., 2016; Ko et al., 2008; MOE, 2015).

Correlation coefficients were computed to show the relationship between the physicochemical properties of liquid products and the GI value, in order to clarify the factors that may contribute to their phytotoxicity (Table S1). Ammonia $\mathrm{N}$ and $\mathrm{Cu}$ were found to be well correlated with the GI value, while the correlation coefficient of soluble $\mathrm{N}($ ammonia $\mathrm{N}+\operatorname{organic} \mathrm{N}$ ) and GI was much lower than that of ammonia $\mathrm{N}$ and GI. During seed germination period, the seeds adsorb water to rupture the coat, then the radicles can elongation. Inorganic N, especially ammonia can be easily absorbed along with water (Hirel et al., 2011). Organic N can be slowly decomposed by microorganisms in soil after application, improving the nitrogen use efficiency of plants compared with chemical fertilizers due to the reduced $\mathrm{N}$ loss through ammonia volatilization or nitrate leaching (Franklin et al., 2017). Negative correlations were noticed for most of the metal ions, except for $\mathrm{Cu}$ and $\mathrm{Ca}$. Ca plays many roles in regulating plant system functions like respiration and cell division, both of which are the predominant activities during seed germination. Two aspects are possibly associated with the negative correlations: 1) metal ions contribute to the high EC value, which would prevent the nutrients uptake by plants if higher than a threshold value $(4 \mathrm{mS} / \mathrm{cm})$; and 2) Komatsuna seeds are sensitive to the toxicity of metal ions. Since the EC values in all the three liquid products were detected to be lower than $4 \mathrm{mS} / \mathrm{cm}$ and exhibit a positive correlation with GI, the sensitivity of Komatsuna seeds should be considered as 
the major reason resulting in the negative correlations. This result agrees with the report by Tam and Tiquia (1994). Besides, the levels of metal ions that are beneficial for plant growth also depend on different plant species. As the seeds mainly use the nutrients stored in cotyledons during seed germination, plant growth assay should be conducted to further explore the effect of metal ions on plant growth. The liquid product with a relatively lower metal ions content or after appropriate dilution can be used as a highquality liquid fertilizer.

\section{Conclusions}

The fertilizer potential of liquid product from hydrothermally treated swine manure was firstly evaluated by investigating the solubilization of $\mathrm{N}, \mathrm{P}$ and organics in swine manure after HTT at different conditions and subsequently conducting seed germination test. HTT technology can significantly enhance the solubilization of nutrients from swine manure, and the resultant liquid product at $150^{\circ} \mathrm{C}$ for 60 min achieved higher than $100 \%$ GI. Considering the results from GI test together with the $\mathrm{pH}$ and $\mathrm{EC}$ of the liquid product, HTT could be proposed as a promising technology for producing safe and value-added liquid fertilizers from swine manure.

\section{Supplementary materials}

Supplementary data of this work can be found in online version of the paper.

\section{Acknowledgement}

This work was financially supported by JSPS KAKENHI Grant Number JP15K00599.

\section{References}


1. Aida, T. M., Maruta, R., Tanabe, Y., Oshima, M., Nonaka, T., Kujiraoka, H., Kumagai, Y., Ota, M., Suzuki, I., Watanabe, M. M., Inomata, H., Smith Jr, R.L., 2017. Nutrient recycle from defatted microalgae (Aurantiochytrium) with hydrothermal treatment for microalgae cultivation. Bioresour. Technol. 228, 186192.

2. APHA, 2012. Standard Methods for the Examination of Water and Wastewater, $22^{\text {nd }}$ ed. American Public Health Association, Washington DC.

3. Arif, N., Yadav, V., Singh, S., Singh, S., Ahmad, P., Mishra, R. K., Sharma, S., Tripathi, D. K., Dubey, N. K., Chauhan, D. K., 2016. Influence of high and low levels of plant-beneficial heavy metal ions on plant growth and development. Front. Environ. Sci. 4, 69.

4. Barber, W. P. F., 2016. Thermal hydrolysis for sewage treatment: a critical review. Water Res. 104, 53-71.

5. CCQC (California Compost Quality Council), 2001. Compost Maturity index. Nevada City, California: California Compost Quality Council. Available at: http://compostingcouncil.org/wp/wp-content/uploads/2014/02/2-CCQC-MaturityIndex.pdf (accessed on 2017-11-07)

6. Crohn, D.M., 2016. Assessing Compost Quality for Agriculture. ANR publications, University of California. Available at: http://anrcatalog.ucanr.edu/pdf/8514.pdf (accessed on 2017-12-20)

7. Eghball, B., and Lesoing, G. W., 2000. Viability of weed seeds following manure windrow composting. Compost Sci. Util. 8, 46-53.

8. Ekpo, U., Ross, A. B., Camargo-Valero, M. A., Williams, P. T., 2016. A comparison 
of product yields and inorganic content in process streams following thermal hydrolysis and hydrothermal processing of microalgae, manure and digestate. Bioresour. Technol., 200, 951-960.

9. Franklin, O., Cambui, C. A., Gruffman, L., Palmroth, S., Oren, R., Näsholm, T., 2017. The carbon bonus of organic nitrogen enhances nitrogen use efficiency of plants. Plant Cell Environ. 40, 25-35.

10. Gai, C., Zhang, Y., Chen, W. T., Zhang, P., Dong, Y., 2015. An investigation of reaction pathways of hydrothermal liquefaction using Chlorella pyrenoidosa and Spirulina platensis. Energ. Convers. Manage. 96, 330-339.

11. Gollakota, A. R. K., Kishore, N., \& Gu, S., 2018. A review on hydrothermal liquefaction of biomass. Renew. Sust. Energ. Rev. 81, 1378-1392.

12. Gollakota, A. R., Reddy, M., Subramanyam, M. D., \& Kishore, N., 2016. A review on the upgradation techniques of pyrolysis oil. Renew. Sust. Energ. Rev. 58, 15431568.

13. Hao, X., Chang, C., Larney, F. J., 2004. Carbon, nitrogen balances and greenhouse gas emission during cattle feedlot manure composting. J. Environ. Qual. 33, 37-44.

14. He, Z., Pagliari, P. H., Waldrip, H. M., 2016. Applied and environmental chemistry of animal manure: a review. Soil Sci. Soc. Chin. 26, 779-816.

15. Hirel, B., Tétu, T., Lea, P. J., \& Dubois, F., 2011. Improving nitrogen use efficiency in crops for sustainable agriculture. Sustainability 3, 1452-1485.

16. Huang, W., Zhao, Z., Yuan, T., Yu, Y., Huang, W., Lei, Z., Zhang, Z., 2017. Enhanced dry anaerobic digestion of swine excreta after organic nitrogen being recovered as soluble proteins and amino acids using hydrothermal technology. 
17. Idowu, I., Li, L., Flora, J. R. V., Pellechia, P. J., Darko, S. A., Ro, K. S., Berge, N. D., 2017. Hydrothermal carbonization of food waste for nutrient recovery and reuse. Waste Manage. 69, 480-491.

18. Khan, S. A., Mulvaney, R. L., Ellsworth, T. R., Boast, C. W., 2007. The myth of nitrogen fertilization for soil carbon sequestration. J. Environ. Qual. 36, 1821-1832.

19. Ko, H. J., Kim, K. Y., Kim, H. T., Kim, C. N., Umeda, M., 2008. Evaluation of maturity parameters and heavy metal contents in composts made from animal manure. Waste Manage. 28, 813-820.

20. Li, C., Wang, X., Zhang, G., Yu, G., Lin, J., Wang, Y., 2017. Hydrothermal and alkaline hydrothermal pretreatments plus anaerobic digestion of sewage sludge for dewatering and biogas production: Bench-scale research and pilot-scale verification. Water Res. 117, 49-57.

21. MOE (Ministry of the Environment), 2015. Uniform National Effluent Standards. Available at: https://www.env.go.jp/en/water/wq/nes.html. (accessed on 2018-0411)

22. Mulvaney, R. L., Khan, S. A., Ellsworth, T. R., 2009. Synthetic nitrogen fertilizers deplete soil nitrogen: a global dilemma for sustainable cereal production. J. Environ. Qual. 38, 2295-2314.

23. Nurdiawati, A., Nakhshiniev, B., Zaini, I. N., Saidov, N., Takahashi, F., Yoshikawa, K., 2018. Characterization of potential liquid fertilizers obtained by hydrothermal treatment of chicken feathers. Environ. Prog. Sustain. 37(1), 375-382.

24. Nurdiawati, A., Novianti, S., Zaini, I. N., Nakhshinieva, B., Sumida, H., Takahashi, 
F., Yoshikawa, K., 2015. Evaluation of hydrothermal treatment of empty fruit bunch for solid fuel and liquid organic fertilizer co-production. Energy Procedia 79, 226232.

25. Suárez-Iglesias, O., Urrea, J. L., Oulego, P., Collado, S., Díaz, M., 2017. Valuable compounds from sewage sludge by thermal hydrolysis and wet oxidation. A review. Sci. Total Environ. 584-585, 921-934.

26. Sun, X. H., Sumida, H., Yoshikawa, K., 2014. Effects of liquid fertilizer produced from sewage sludge by the hydrothermal process on the growth of Komatsuna. Brit. J. Environ. Clim. Change 4, 261-278.

27. Tam, N. F. Y. and Tiquia, S., 1994. Assessing toxicity of spent pig litter using a seed germination technique. Resour. Conserv. Recy. 11, 261-274.

28. Teenstra, E., Vellinga, T., Aektasaeng, N., Amatayakul, W., Ndambi, A., Pelster, D., Germer, L., Jenet, A., Opio, C., Andeweg, K., 2014. Global assessment of manure management policies and practices. Livestock Res. Rep. 844. Wagningen, The Netherlands: Wagningen UR.

29. Tiquia, S. M. and Tam, N. F. Y., 1998. Elimination of phytotoxicity during cocomposting of spent pig-manure sawdust litter and pig sludge. Bioresour. Technol. $65,43-49$.

30. Yuan, T., Huang, W., Lei, Z., Zhao, Z., Zhang, Z., 2017. Effects of different alkalis on hydrolysis of swine manure during dry anaerobic digestion and resultant nutrients availability. Int. Biodeter. Biodegr. 123, 138-145.

31. Zheng, J. L., Zhu, M. Q., Wu, H. T., 2015. Alkaline hydrothermal liquefaction of swine carcasses to bio-oil. Waste Manage. 43, 230-238. 
Table 1 Characteristics of liquid products used for seed germination test.

\begin{tabular}{lcccccccccccc}
\hline & $\mathbf{p H}$ & $\begin{array}{c}\mathbf{E C} \\
(\mathbf{m S} / \mathbf{c m})\end{array}$ & $\begin{array}{c}\mathbf{S O C} \\
(\mathbf{m g} / \mathbf{L})\end{array}$ & $\begin{array}{c}\text { Soluble N } \\
(\mathbf{m g ~ N} / \mathbf{L})\end{array}$ & $\begin{array}{c}\text { Soluble P } \\
(\mathbf{m g} \mathbf{P} / \mathbf{L})\end{array}$ & $\begin{array}{c}\mathbf{K} \\
(\mathbf{m g} / \mathbf{L})\end{array}$ & $\begin{array}{c}\mathbf{M g} \\
(\mathbf{m g} / \mathbf{L})\end{array}$ & $\begin{array}{c}\mathbf{C a} \\
(\mathbf{m g} / \mathbf{L})\end{array}$ & $\begin{array}{c}\mathbf{F e} \\
(\mathbf{m g} / \mathbf{L})\end{array}$ & $\begin{array}{c}\mathbf{A l} \\
(\mathbf{m g} / \mathbf{L})\end{array}$ & $\begin{array}{c}\mathbf{Z n} \\
(\mathbf{m g} / \mathbf{L})\end{array}$ & $\begin{array}{c}\mathbf{C u} \\
(\mathbf{m g} / \mathbf{L})\end{array}$ \\
\hline Raw & 7.93 & 1.25 & 973.8 & 223.2 & 46.4 & 50.9 & 23.7 & 39.34 & N.D. & 2.15 & N.D. & 3.92 \\
manure & 7.80 & 1.70 & 2130.8 & 409.2 & 128.8 & 59.7 & 68.1 & 28.92 & 0.78 & 0.31 & 1.33 & 0.54 \\
$\mathbf{L 1 5 0 - 6 0}^{\mathbf{a}}$ & & & & & & & & & & & & \\
$\mathbf{L 1 8 0 - 3 0}^{\mathbf{a}}$ & 7.57 & 1.78 & 3963.0 & 529.5 & 107.4 & 224.5 & 98.1 & 14.81 & 4.66 & 1.23 & 3.04 & 0.10 \\
$\mathbf{L 2 0 0 - 6 0}^{\mathbf{a}}$ & 7.27 & 2.00 & 2626.0 & 547.3 & 108.4 & 247.8 & 157.2 & 15.43 & 5.05 & 1.46 & 3.39 & n.d. \\
\hline
\end{tabular}

372 *EC, electrical conductivity; SOC, soluble organic carbon. N.D., not detectable. 


\section{Figures}

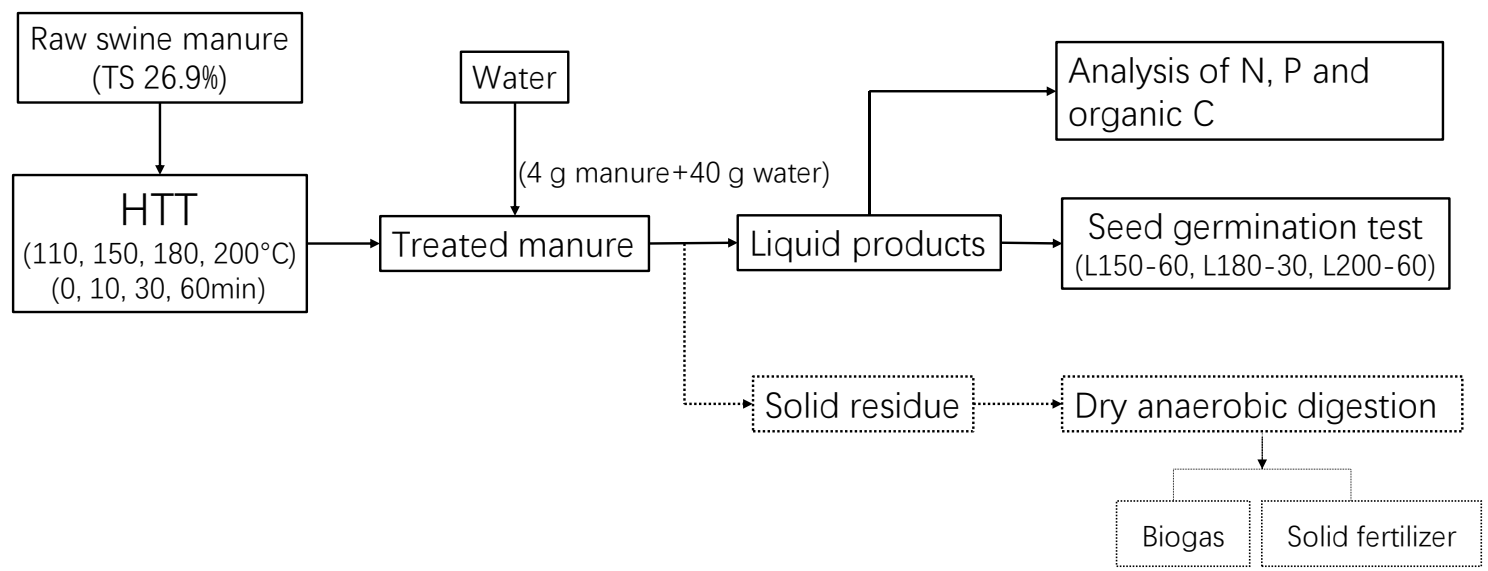

Fig. 1 Schematic of experimental setup in this study. HTT, hydrothermal treatment; Lx-

$\mathrm{y}$, the liquid products from HTT at temperature of $\mathrm{x}\left({ }^{\circ} \mathrm{C}\right)$ for $\mathrm{y}$ min. Solid line, the experiments did in this study; Dash line, the suggested treatment method for solid residue after water extraction. 


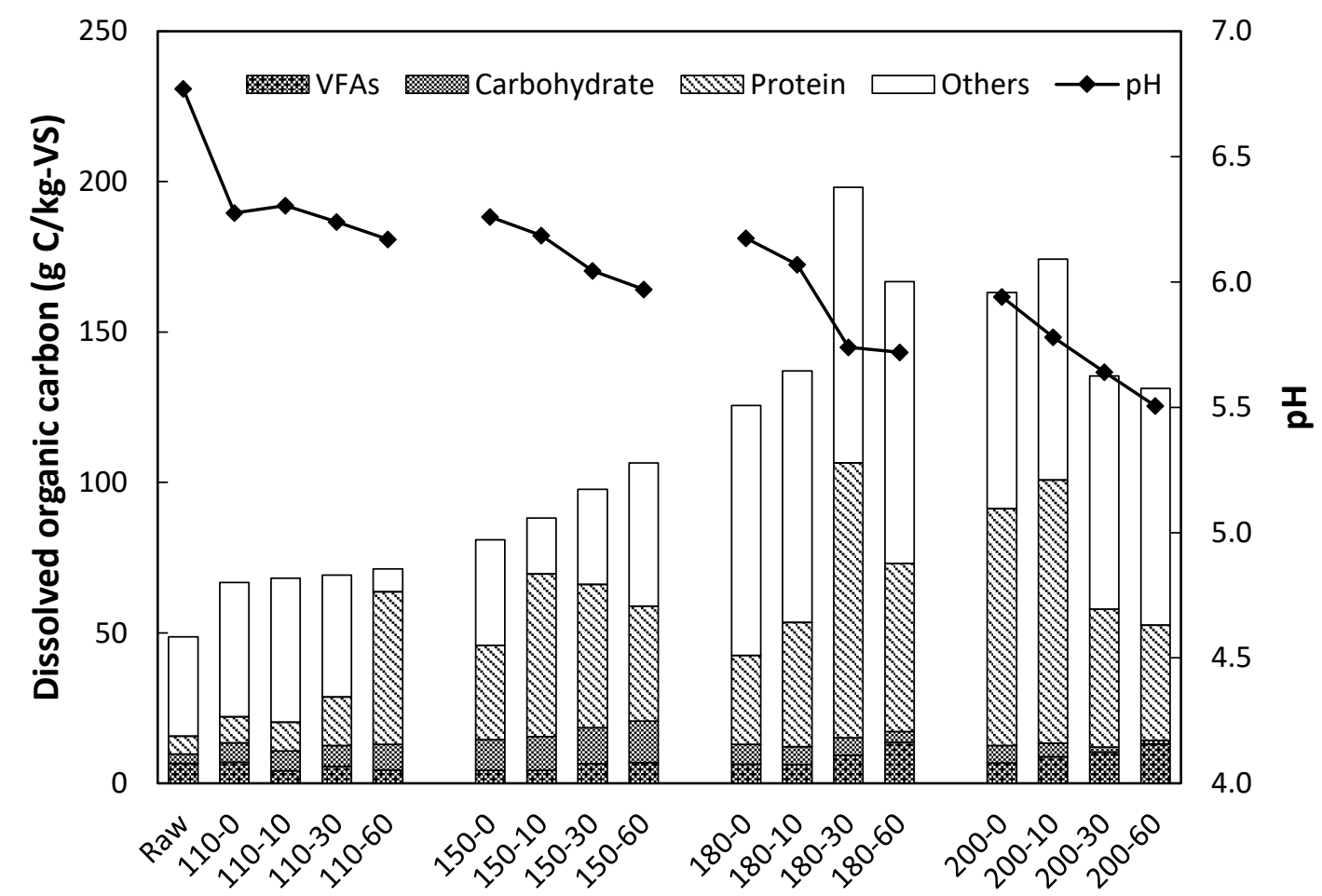

Fig. 2 Effect of hydrothermal treatment (HTT) on organic carbon dissolution from swine manure and the resultant $\mathrm{pH}$ of treated swine manure. ' $\mathrm{x}-\mathrm{y}$ ' denotes the conditions of HTT at $\mathrm{x}\left({ }^{\circ} \mathrm{C}\right)$ for $\mathrm{y}$ min. Raw-raw swine manure without HTT. 

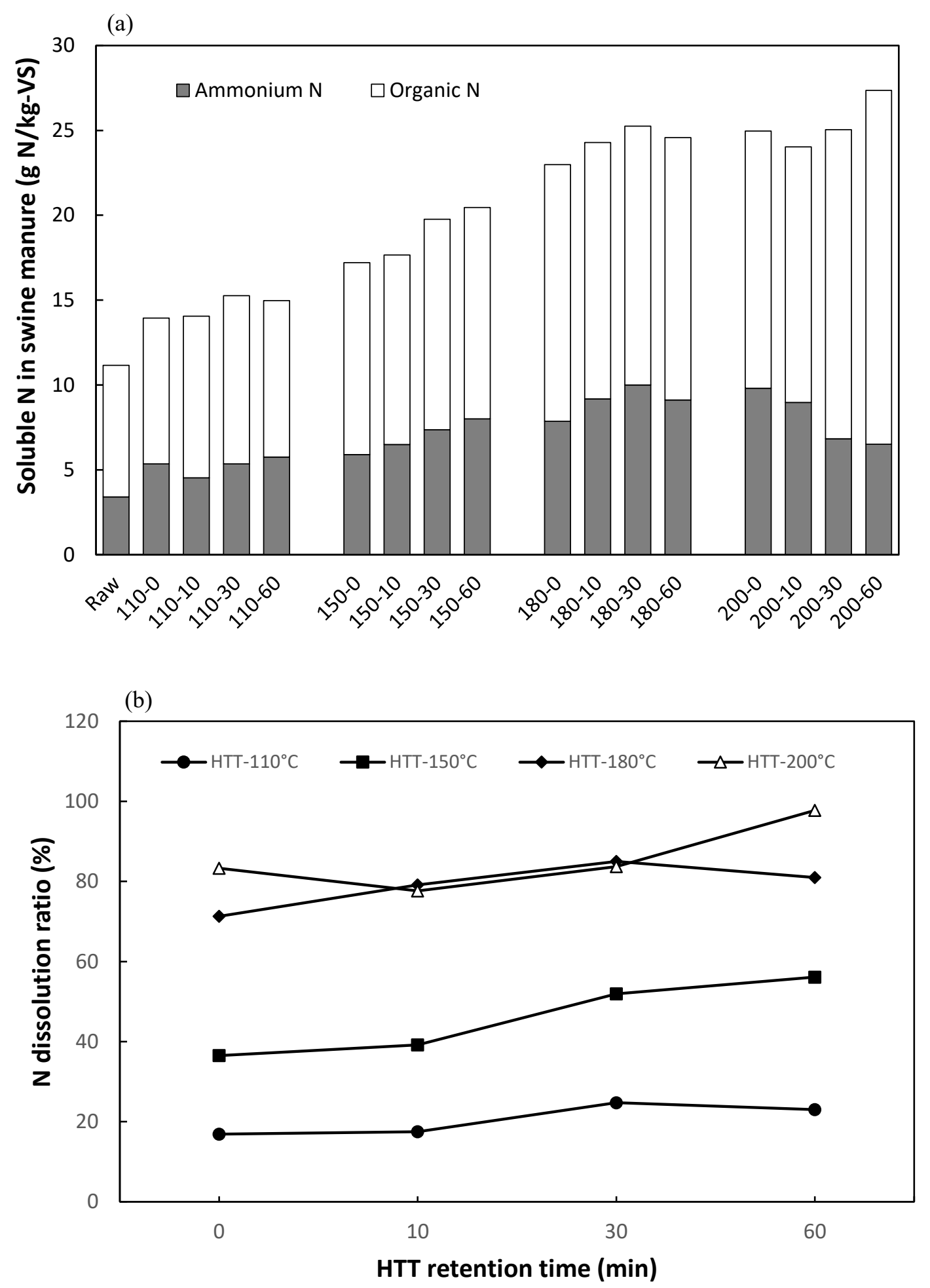

Fig. 3 Effect of hydrothermal treatment (HTT) on N dissolution from swine manure. (a)

Soluble $\mathrm{N}$ in swine manure, and (b) $\mathrm{N}$ dissolution ratio. ' $\mathrm{x}-\mathrm{y}$ ' denotes the conditions of 
HTT at $\mathrm{x}\left({ }^{\circ} \mathrm{C}\right)$ for y min. Raw-raw swine manure without HTT.

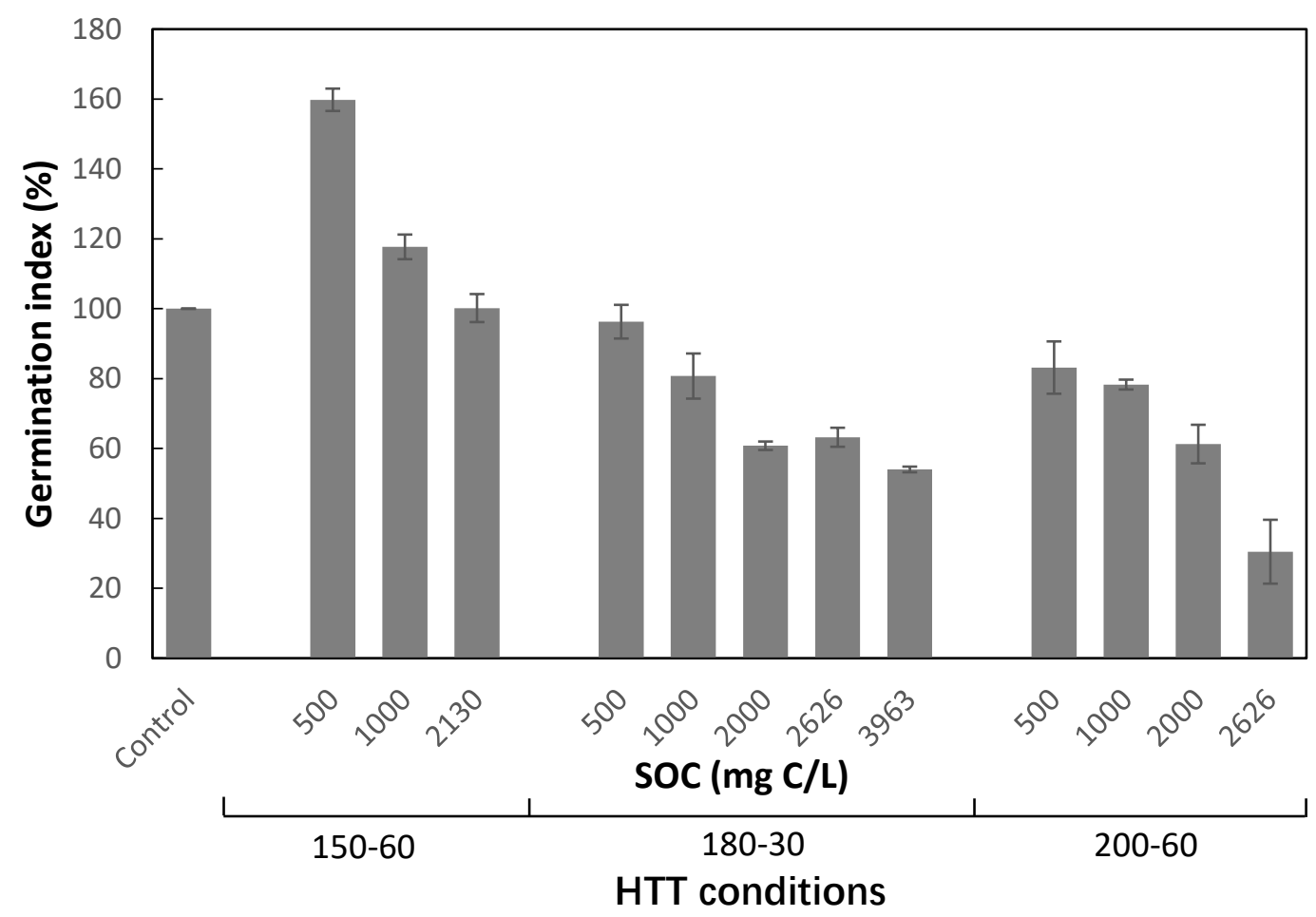

Fig. 4 Germination test by using the liquid products from hydrothermally treated swine manure. 


\section{Supplementary Materials}

\section{Fertilizer potential of liquid product from hydrothermal treatment of swine manure}

Tian Yuan ${ }^{\mathrm{a}, 1}$, Yanfei Cheng ${ }^{\mathrm{a}, 1}$, Weiwei Huang ${ }^{\mathrm{b}}$, Zhenya Zhang ${ }^{\mathrm{a}}$, Zhongfang Lei ${ }^{\mathrm{a},{ }^{*}}$, Kazuya Shimizu ${ }^{\mathrm{a}}$, Motoo Utsumi ${ }^{\mathrm{a}}$

${ }^{a}$ Graduate School of Life and Environmental Sciences, University of Tsukuba, 1-1-1 Tennodai, Tsukuba, Ibaraki 305-8572, Japan.

${ }^{b}$ Key Laboratory of Coal Gasification and Energy Chemical Engineering of Ministry of Education, East China University of Science and Technology, No. 130 Meilong Road, Shanghai 200237, China

*Corresponding author.

Tel./Fax: +81 29853 6703. E-mail: lei.zhongfang.gu@u.tsukuba.ac.jp

${ }^{1}$ The authors contributed equally to this work. 
Table S1 Correlation coefficients between germination index and related parameters at different SOC levels.

SOC500, SOC1000, and SOC2000 denote the soluble organic concentration of 500, 1000 and $2000 \mathrm{mg}$ $\mathrm{C} / \mathrm{L}$, respectively.

\begin{tabular}{lccc}
\hline \multirow{2}{*}{ Parameters } & \multicolumn{3}{c}{ Germination index (GI) } \\
\cline { 2 - 4 } & SOC500 & SOC1000 & SOC2000 \\
\hline Electric conductivity & 0.766 & 0.751 & 0.679 \\
(EC) & 0.991 & $1.000^{*}$ & $0.999^{*}$ \\
Ammonia N & 0.360 & 0.457 & 0.514 \\
Soluble N & 0.803 & 0.862 & 0.893 \\
Ortho-P & 0.835 & 0.888 & 0.916 \\
Soluble P & -0.896 & -0.844 & -0.807 \\
$\mathrm{~K}$ & -0.413 & -0.315 & -0.252 \\
$\mathrm{Mg}$ & 0.939 & 0.970 & 0.984 \\
$\mathrm{Ca}$ & -0.940 & -0.899 & -0.868 \\
$\mathrm{Fe}$ & -0.881 & -0.827 & -0.788 \\
$\mathrm{Al}$ & -0.743 & -0.668 & -0.617 \\
$\mathrm{Zn}$ & $0.997^{*}$ & $1.000^{*}$ & 0.995 \\
$\mathrm{Cu}$ & & &
\end{tabular}


(a)
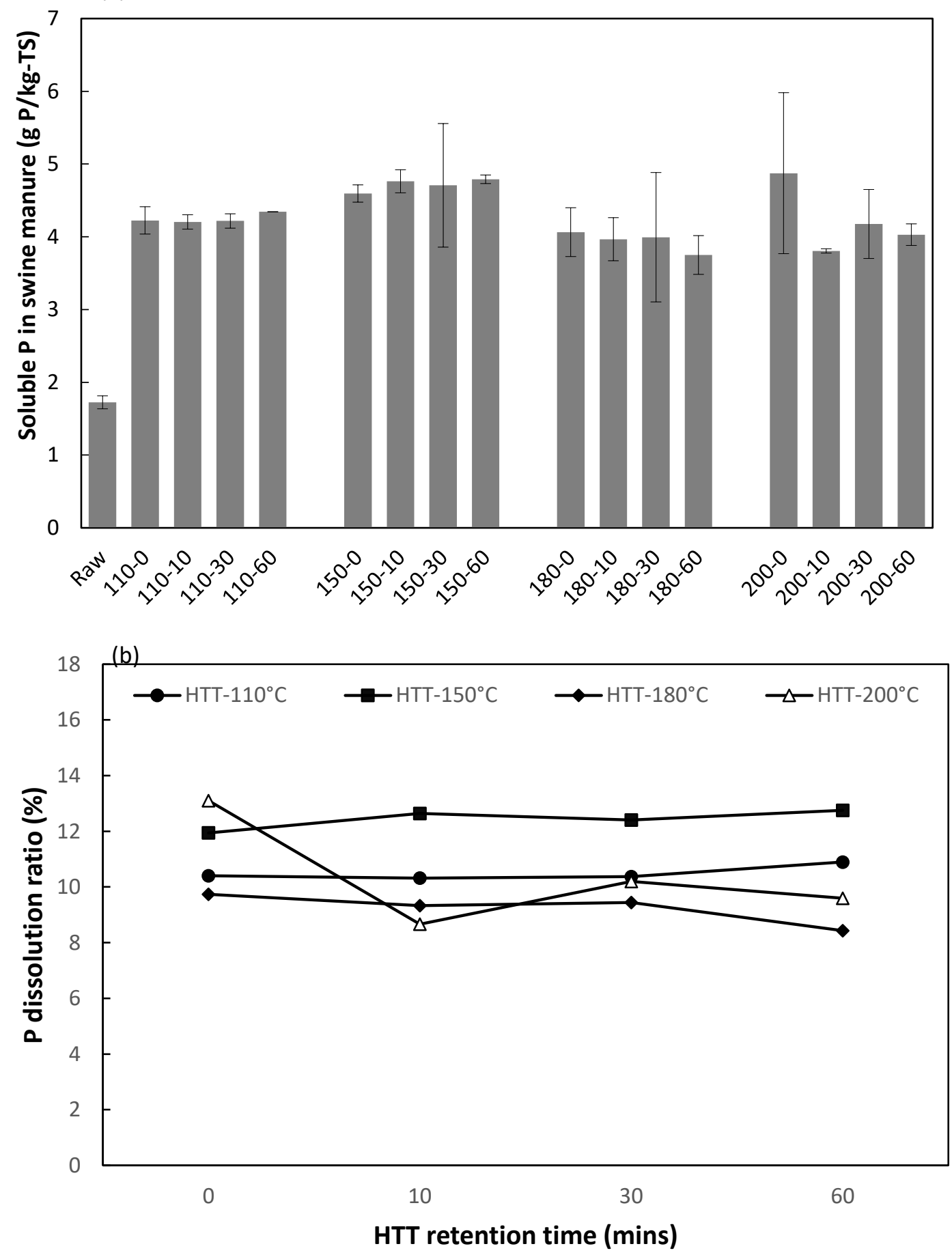

Fig. S1 Effect of hydrothermal treatment (HTT) on P dissolution from swine manure. (a) Soluble P in swine manure and (b) P dissolution ratio. ' $\mathrm{x}-\mathrm{y}$ ' denotes the conditions of HTT at $\mathrm{x}\left({ }^{\circ} \mathrm{C}\right)$ for $\mathrm{y}$ min. Rawraw swine manure without HTT. 